\title{
ENVIRONMENTAL PROACTIVITY ON ENVIRONMENTAL PERFORMANCE: AN EXTENSION OF NATURAL RESOURCE-BASED VIEW THEORY (NRBV)
}

\author{
Jeya Santhini Appannan ${ }^{1 *}$, Ridzwana Mohd Said ${ }^{1}$, Tze San Ong ${ }^{1}$ and Rosmila Senik ${ }^{1}$ \\ ${ }^{1}$ School of Business and Economics, Universiti Putra Malaysia, Malaysia
}

\begin{abstract}
Extensive use of global resources and the associated environmental impacts continue to grow. As a result, green operations have received continuous attention from the business sector in the recent years. However, only a few studies unpacked its dimension and examined towards environmental management accounting (EMA) and firm's performance. The purpose of this paper is to (i) review the connection of holistic accounting approach of EMA and environmental performance in the extant literature and (ii) deepen the theory of NRBV by incorporating environmental proactivity as a moderator in the framework to provide additional theoretical explanation to environmental performance in the context of ISO 14001 companies in Malaysia. Using the data of 145 companies, this study revealed that environmental proactivity moderates the relationship between EMA and environmental performance. Interestingly, we also found that EMA showed positive relationship on environmental performance. The research findings will be particularly important for ISO 14001 companies in developing their strategies and policies to achieve sustainable performance. Furthermore, the outcome will give some remarkable insights for managers to identify current standing of their firm's environmental performance.
\end{abstract}

\author{
ARTICLE HISTORY \\ Received:13-1-2020 \\ Accepted:4-3-2020
}

\section{KEYWORDS}

Dynamic capabilities;

EMA;

Environmental

performance;

environmental proactivity;

Malaysia

\section{INTRODUCTION}

The growing environmental crisis has led to an increased focus on public health. The World Health Organization (WHO) estimated that about a quarter of all human diseases today are due to continuous exposure to environmental pollution. Furthermore, based on the statistics released by WHO, the impact of climate change has caused 160,000 deaths annually, and the rate is predicted to double by 2020 (Mekhilef et al., 2011). Due to the impairment of environmental quality, WHO and partners, such as the United Nations (UN) Environment, are developing ways to promote mutual understanding between humanity and nature.

The United Nations Environment Programme reported that the number of environmental laws has increased 38 -fold globally since the Stockholm declaration on the human environment in 1972. This includes the Durban Platform and Rio+20, the Kyoto Protocol which has been extended to 2020. Additionally, the Paris Agreement sets to keep global temperature increases below 2.0 degrees, while urging further efforts to limit the increase to 1.5 degree Celsius $\left({ }^{\circ} \mathrm{C}\right)$. In the year 2017, based on the record released by Climate Action Tracker (CAT), among all the world's largest and most advanced economies, only two governments recorded to achieve a $1.5^{\circ} \mathrm{C}$ Paris Climate Agreement which is Gambia and Morocco. The US and China are critically insufficient whereas India is on track to a $2.0^{\circ} \mathrm{C}$ level.

The formation of regulations, followed by its extension or modification is clearly showing that we are still not ready or have not found any toolkit yet to act globally to address the main "story". Thus, it is clear that stringent environmental enforcement no longer solves this issue as a whole Mehrabi et al. (2019) projected a revisit on low carbon strategies. Considering this call and the urgency to make people aware of using natural resources sustainably, the burden now has fallen to the corporate level. This paper, therefore, emerged as an important basis to further examine the determinants of environmental performance.

\section{Malaysia and its environment}

Malaysia is a country in Southeast Asia in which its location is separated by the South China Sea into two similarly sized regions, Peninsular Malaysia and East Malaysia. Malaysia's most valuable mineral resources are its reserves of natural gas and petroleum. Refined petroleum, crude oil, and more recently, liquefied natural gas together make up a significant proportion of the country's export earnings.

Malaysia is rich in its natural resources. While extracting natural resources in making profit, Malaysian firms owe a great duty in return to save the environment. In order to return to healthier earth back to the future generations, Malaysia is trying its best to achieve sustainable goals as outlined under the UN adopted 2030 Agenda. Thus, a proper capability system seems to become an important prerequisite before sustainability performance is viable. 
Despite the implementation of various environmental regulations, it is disappointing that these laws and policies have not been potentially reaching the aim of protecting the environment from human impacts. This could also be explained by Malaysia's Environmental Performance Index (EPI) which was ranked $64^{\text {th }}$ place in the year 2016 and has fallen to the position of $75^{\text {th }}$ in the year 2018. Switzerland leads the world in sustainability, followed by France, Denmark, Malta, and Sweden.

Therefore, an immediate shift is needed to generate a low-carbon economy. As for a solution, Gan et al. (2013) proposed that Malaysia's carbon dioxide content may confidently drop to 358 million tons $\left(\mathrm{MtCO}_{2}\right)$ by the year 2035 with the help of energy-efficient improvements. Therefore, collective support from all parties is needed, particularly, business players which are the utmost essential (Alisjahbana, 2016) to support the achievement of environmental protection. Consequently, this study intended to investigate the extent of companies to fully incorporate sustainability goals into their core business operations, creating a win-win situation for them such as venturing into a new market and at the same time, saving the environment by connecting the holistic approach of accounting which is environmental management accounting (EMA).

\section{LITERATURE REVIEW}

\section{Environmental performance (EP)}

The word "environmental," however, is always used in reference to human interaction with the ecosystem. To increase precision, a researcher further reasonably viewed "environmental" as a subdivision of the broader concept of "ecological," for example, the intersection of human activities and ecological systems. Furthermore, Friedman (1970) found that corporate environmental performance constitutes an important domain of corporate social responsibility. The multiple domains evolved, perhaps, due to no consensus on EP.

Table 1 shows that there is an absence of an ideal operational definition of EP, and notably, inconsistency in the measurement used to assess EP in previous studies. On the other hand, more environmentally friendly accomplishment as a potential business opportunity is needed to walk the process towards a world-class EP but again, it was not always intuitive to managers. In this regard, considerable studies have been done in the past and have documented the findings in realising EP.

It is widely known that studies on EP can help to increase the perceived accuracy and credibility of their environmental reporting practices, build societal confidence, and increase legitimacy (Braam et al., 2016). However, some contradictory empirical findings indicated that the same use of antecedents but in a different context does not necessarily lead to performance improvement (Lee \& Rhee, 2007). Various explanations have been proposed to demonstrate these inconsistencies, such as the employment of small sample size (Konar \& Cohen, 2001), lack of timely and accurate data (Hsu et al., 2013), or use of sustainability as a concept rooted in its complexity (Searcy \& Elkhawas, 2012). Another explanation would be probably the dilemma of a vast array of instruments available for measurement. For example, Braam et al. (2016) could not materialize their results because data such as the toxic releases inventory was unavailable and sample respondents were selected from specific cultural settings.

As a result of a mixed conclusion, it is highly doubtful that the companies could achieve better environmental performances. Therefore, it is necessary to develop tools that could enable companies to understand their impact on the environment in which they operate (Christ \& Burritt, 2016). In these circumstances, scholars have proven that environmental accounting tools can be a solution to connect and motivate a company's employees to embrace more environmentally-friendly behaviours, and at the same time, improve performance.

Table 1. Summary of scholarly definitions for the concept of environmental performance

\begin{tabular}{|c|c|}
\hline Source & Definition \\
\hline $\begin{array}{l}\text { Roberts and Gehrke } \\
\text { (1996) }\end{array}$ & $\begin{array}{l}\text { the extent to which firm processes and practices maximize efficient use of } \\
\text { resources, reduce wastage and environmental risks. }\end{array}$ \\
\hline Wagner et al. (2002) & $\begin{array}{l}\text { organization's behaviour vis-à-vis natural environment in terms of how it goes } \\
\text { about to consume available resources with strong commitment to have a strict } \\
\text { check on pollution emissions }\end{array}$ \\
\hline $\begin{array}{l}\text { Nawrocka and Parker } \\
(2009)\end{array}$ & $\begin{array}{l}\text { an overview of the use of operational performance indicators that evaluate the use } \\
\text { of resources, waste disposal, emissions, or water consumption. }\end{array}$ \\
\hline Albertini (2014) & the effects of firm's activities on the natural environment \\
\hline $\begin{array}{l}\text { De Burgos-Jimenez et } \\
\text { al. (2013) }\end{array}$ & $\begin{array}{l}\text { the actual outcomes of environmental efforts in terms of protecting the } \\
\text { environment. }\end{array}$ \\
\hline Dubey et al. (2015) & $\begin{array}{l}\text { the relationship between the organization and the environment. It includes the } \\
\text { environmental effects of resources consumed, the environmental impacts of the } \\
\text { organizational process, the environmental implications of its products and } \\
\text { services, the recovery and processing of products, and meeting legal } \\
\text { environmental requirements. }\end{array}$ \\
\hline
\end{tabular}




\section{Environmental management accounting (EMA)}

Sustainability accounting is defined as an approach related to appropriate costs that are deducted from accounting profits to cover the outgoings, in order to ensure that the stock of natural capital is not depleted (Bebbington \& Gray, 2001). In particular, EMA is known as a part of environmental accounting which appears like a beneficial tool to overcome drawbacks of traditional management accounting to a better understanding and quantification of environmental issues in the decision-making process (Burritt et al., 2002; de Beer and Friend, 2006).

The International Federation of Accountants (IFAC) in its International Guidance Document: defined EMA as '...the management of environmental and economic performance through the development and implementation of appropriate environment-related accounting systems and practice which may include reporting and auditing in some companies' (IFAC, 2005, p.19).

Since EMA contains various tools and techniques for targeted information through collection, analysis, and communication, this led EMA to take the form of managerial technology that combines knowledge, methodology, and practices as well as administer environmental management and economic outcomes (Rikhardsson et al., 2005).

Among the types of EMA tools is Material Flow Cost Accounting (MFCA), Activity-Based Costing (ABC), and LifeCycle Assessment (LCA) (Tajelawi et al., 2015). The importance of EMA can be seen when MFCA has integrated into ISO 14051 (ISO, 2011) for an organization to trace and quantify monetary and non-monetary flows to produce a lowcarbon supply chain. EMA was extensively examined in numerous sectors and industries such as local government (Qian et al., 2011); automobiles (Jasch \& Lavicka, 2006); iron and steel (Zhou et al. 2017); pulp and paper (Setthasakko, 2010); and manufacturing (Jalaludin et al., 2010).

It was also noticed in the prevailing literature that the majority of the existing EMA literature have been linked to environmental disclosure and cost measurements. Therefore, it can be comfortably concluded that there is a parallel increase in studies of EP as long as consideration for environmental reporting increases (Yakhou \& Doreweiler, 2004). Thus, due to the applicability and resource durability, environmental initiatives are often questioned in translating improved performance. Some authors went beyond reporting and focused on EMA to achieve better performance and competitive advantage. For instance, Latan et al. (2018) assessed the role of EMA in manufacturing companies in Indonesia and the evident relationship between EMA and a firm's environmental performance. Another study was also carried out in Indonesia by Christine et al. (2019) which concluded a similar outcome.

It was noted that issues connected with inefficiencies in material, labour, and energy use, a high degree of waste and losses, and a rise in the cost of all inputs explains the conventional accounting system. If the EMA development or extension is not well considered, this would result in severe environmental problems that could be too late to recover. Considering the work of Agustia, Sawarjuwono, and Dianawati, (2019), companies need a holistic system like EMA to achieve a win-win approach for both planet and business. The benefits derived from this managerial technology unfold and guide managers with information related to financial and non-financial matters, and seek improvement in the coordination and communication of material and energy usage in organizations that can be used to translate improved performance. With this in mind, this study aims to link EMA and EP moderated by environmental proactivity.

\section{Environmental proactivity (EPA)}

Buysse and Verbeke (2003) interpreted environmental proactivity as a willingness of the company to execute environmental protection measures voluntarily, primarily based on prevention. Relatedly, Menguc and Ozanne (2005) referred to EPA as a voluntary action beyond compliance undertaken by a company to eliminate or reduce the harmful impacts of its operations on the natural environment. Furthermore, González-Benito and González-Benito (2006) detailed EPA into three components, namely planning and organisational practices (setting of environmental management system), operational practices (design and development of more environmentally conscious products and processes), and communicational practices (organisation's communication of its environmental impacts to the public). Subsequently, Alrazi (2015) simplified González-Benito and González-Benito (2006) work into combining the first two components (planning and organizational practices) into one established component known as environmental management systems and therefore, referred to environmental proactivity as a 'process'. Besides, Garces-Ayerbeetal (2012) defined environmental proactivity as a propensity to go extra than fulfilling with legislation.

The consensus on EPA is the presence of intentional participation, which consciously seeks engagement to contribute to society, in order to reduce and avoid adverse effects. Studies so far have used this construct as an independent variable or a final output. In other words, it was studied in both edges as an exogenous and endogenous variable. For example, Sambasivan et al. (2013) developed their framework grounded by the theory of resource-based view and stakeholder theory. They found that EPA among Malaysian firms is positively related to operational performance, organizational learning, environmental performance, stakeholder satisfaction, and financial performance. The authors measured EPA as outlined by González-Benito and González-Benito (2006), into three components (planning and organisational practices, operational practices, and communicational practices). The authors further concluded that Malaysian companies consider attempts to reduce the company's negative environmental effects and at the same time enhancing the business performance, which is a potential win-win situation for the firm. Due to the multiple magnitudes, EPA has been known as specific capabilities that enable companies to go the extra mile than fulfilling the ground environmental regulations (Aragon-Correa \& Sharma, 2003), in which these magnitudes are referred to as valuable and rare to imitate, and promises superior performance. 
On the other hand, González-Benito and González-Benito (2005) revealed that some dimensions of EPA have positive and negative effects on performance. For future work, the authors recommended a disaggregated way to incorporate EPA between different patterns or strategies and different types of performance indicators. Relatedly, Demirel, and Kesidou (2011) stated that a direct relationship between environmental efforts and the environmental performance of firms is not always conclusive. As such, this paper investigated the gaps that arise from past studies and drew an alternative approach examining indirect links instead. Therefore, this paper argues that higher EPA made the relationship between EMA and EP stronger.

\section{THE RESEARCH THEORIES}

\section{Natural resource-based view (NRBV) theory}

It was observed that the existing Resource-Based View (RBV) theory had significant drawbacks that ignored the presence of the natural environment. Due to this issue, the NRBV appeared to fill the gap (Hart, 1995; Hart and Dowell, 2011). The NRBV offers a connection between the natural environment and a firm's resources and capabilities. The NRBV and its extensions (Hart, 1995; Hart and Dowell, 2011) proposed three strategies for improved environmental performance. These are pollution prevention, stewardship, and sustainable development.

This study expected the use of EMA resulted in better performance using the theory of NRBV.

\section{Extension of NRBV theory underpinning theory of Dynamic Capabilities (DC)}

The theory of DC is also known as an addition to the RBV theory (Barreto, 2010). RBV provides plausible reasons that by obtaining a strong and valuable set of resources or capabilities, organizations can gain a competitive advantage. However, this theory did not reveal why and how organizations have still yet to preserve and maintain this competitive advantage in the dynamic environment (Teece et al., 1997). Synthesising various viewpoints, Teece (2014) simplified DC into three primary clusters which are (1) identification, development, co-development, and assessment of technological opportunities in relation to customer needs (sensing); (2) mobilisation of resources to address needs and opportunities, and to capture the value of doing so (seizing); and (3) to continue the renewal (transforming). These sets of capabilities provide an analytical framework that helps to capture the organisation's response to a changing business environment. This may involve changes to the business model, mergers, acquisitions, and divestments (Teece, 2010). EMA (appears in Figure 1) best constitutes the theory of DC as it owns a specific capability which is capable to sense the need of information required by the internal and external stakeholders. This investment would subsequently lead to a new path and alter the existing business goals to be more environmentally committed.

In the situation of sustainable development considered as a moving target, applying EMA as a single approach appears inadequate for a better EP. Schaltegger (2018) claimed that EMA can play a decisive role in supporting managers and companies to come closer to the target of sustainable development. However, EMA is needed to be studied more broadly in explaining how this tool can influence its externalities towards society as a whole. On the other hand, it was found that EPA ensures competitive advantage in dynamic environments. Another capability drawn from the theory of DC is the capability to sense the demand of internal and external stakeholders and seize its information by going beyond basic compliance, and more likely to deploy and exploit the company's resources and capabilities in accomplishing uniqueness in the business model, which is hard to imitate by competitors in ensuring secured market position. This effort eventually resulted in greater performance.

\section{Hypotheses development}

Past studies viewed EMA as a managerial technology that creates and drives companies' values to a higher level of environmental and economic value (Rikhardsson et al., 2005). Although EMA is justifiable enough to perform superior performance, yet there are empirical studies that showed negative or no relation between these two links (Setthasakko, 2010; Ariffin, 2016). In that manner, it is necessary to consider the effect of the third variable as a moderator that can strengthen this relationship.

Furthermore, studies in the past were mostly related to the exploration of the antecedent of EPA rather than testing it as a moderator. As to date, this variable was tested as a moderator in one study in China by Liu, Zhu, and Seuring (2017). Apart from this, it was also noticed in the past literature that EPA was measured using various indicators and multiple definitions. Studies also found mixed results in performance or competitive advantages. EPA is embraced to measure its moderating effect on the framework postulated in this paper as shown in Figure 1. The outcome tends to be a remarkable contribution to performance. Therefore, this paper proposed:

H1: The relationship between EMA use and environmental performance is moderated by environmental proactivity.

\begin{tabular}{|c|c|c|}
\hline $\begin{array}{c}\text { Environmental } \\
\text { management } \\
\text { accounting }\end{array}$ & $\uparrow$ \\
\cline { 2 - 3 } & $\begin{array}{c}\text { Environmental } \\
\text { proactivity }\end{array}$ \\
Figure 1. Research model & $\begin{array}{c}\text { Environmental } \\
\text { performance }\end{array}$ \\
\hline
\end{tabular}




\section{METHODOLOGY}

Companies certified with ISO 14001 generally have more concern on an environmental issue (Rao, 2002). However, the fast-growing of ISO 14001 certified companies, the expense of contamination and other harm to the regular habitat has also seen a parallel increase which has posed a severe threat to human beings. As environmental degradation is worsening despite the increase of certified companies of ISO 14001, it is important for stakeholders to go beyond compliances to deliver more than is required by law (Vishwakarma, Nema, \& Sangle, 2019). Thus, it is important to understand the real standing of EP of ISO 14001 companies in protecting the environment.

The target population consisted of ISO 14001 certified companies in Malaysia drawn from a list provided by SIRIM QAS International Sdn. Bhd. A systematic sampling method was applied. A total of 145 responses were collected from managers of ISO 14001 certified companies in Malaysia and the data was subjected to a structural equation analysis using Smart PLS.

A quantitative approach using a self-administered questionnaire was adopted. This research utilised a variety of validated scales to measure major constructs illustrated in the framework (Figure 1). Most of the validated scales were adapted to fit in the sample of the research (Table 2). A seven-point Likert scale, with 1 as strongly disagree and 7 as strongly agree, was used to evaluate the statements, with the exception of demographic details. In addition, a pre-test was also carried out to finalize the acceptability of the questionnaire.

Table 2. Source of constructs

\begin{tabular}{cc}
\hline Construct & Source \\
\hline Environmental performance (EP) & Sambasivan, Bah, \& Ho (2013) \\
Environmental management accounting & Latan et al. (2018) \\
(EMA) & Liu, Zhu, \& Seuring (2017) \\
Environmental proactivity (EPA)
\end{tabular}

All variables in this paper were measured by multiple statements. Next, a post hoc procedure was also conducted after data collection to check whether a single factor is accountable for variance in the data (Chang et al., 2010). It was found that common method variance is not a pervasive issue in this paper.

Overall, 300 target respondents were contacted to participate in the survey. However, only 145 were usable at the end of the data screening procedure. All analyses were performed in the Statistical Package for the Social Sciences and SmartPLS software programmes. The latter software utilizes structural equation modelling of partial least squares (PLSSEM) approach to increase its predictive usefulness by maximizing the variance of key target variables by different explanatory variables (Hair et al., 2014).

This paper chose PLS-SEM over covariance-based SEM for two reasons. Firstly, it is because EPA is not part of the NRBV theory and is embraced as the key construct to measure EP. The focus of this paper is more on the explanative capacity by components, rather than reproducing of the covariance matrix to achieve model fit (Hair et al., 2014). Secondly, the structural model of this study is complex (for example, many constructs and many indicators are involved), especially since all independent variables were measured in various dimensions.

\section{FINDINGS}

\section{Respondent demographics}

Based on the analysis, the response rate was $24.95 \%$. A total of $93 \%$ of the respondents were from the management level who were able to explain their company's environmental performance. The highest respondents came from the manufacturing sector which recorded the highest percentage of $81 \%$ in this paper. It can be seen that the majority of the firms have been in business for more than 20 years and the majority of the sampled firms have below 200 employees.

\section{Measurement model}

Table 3 depicts the assessment of construct reliability as well as convergent validity for the variables of this paper. The composite reliability (CR) values of 0.802 (EPA), 0.865 (EP), 0.853 (EMA), show that these constructs have a high level of internal consistency. Similarly, convergent validity was assessed using the average variance extracted (AVE). The result showed that all constructs achieve the minimum threshold value of 0.5 for the AVE, which is also an indication that the items explain more than 50\% of the variances of the construct (Hair, et al., 2014).

In order to avoid problems of multicollinearity, an assessment of discriminatory validity is needed. In this regard, this paper assessed discriminatory validity with the most widely used method, known as Fornell and Larcker criteria, as well as the heterotrait-monotrait (HTMT) ratio. These have been demonstrated in Tables 4, 5, and 6. Thus, it clearly showed that all the constructs are substantially different from one another, implying that each construct is distinctive and captures phenomena that are not represented by other constructs in the model (Hair et al., 2014). 
Table 3. Factor loadings and reliability for constructs

\begin{tabular}{|c|c|c|c|c|}
\hline Construct & Item & Loading & AVE & CR \\
\hline \multirow{5}{*}{ EP } & EP1 & .741 & \multirow{5}{*}{.563} & \multirow{5}{*}{.865} \\
\hline & EP2 & .777 & & \\
\hline & EP3 & .744 & & \\
\hline & EP4 & .793 & & \\
\hline & EP5 & .693 & & \\
\hline \multirow{4}{*}{ EMA } & EMA1 & .748 & \multirow{4}{*}{.592} & \multirow{4}{*}{.853} \\
\hline & EMA2 & .781 & & \\
\hline & EMA3 & .793 & & \\
\hline & EMA4 & .754 & & \\
\hline \multirow{4}{*}{ EPA } & EPA1 & .709 & \multirow{4}{*}{.503} & \multirow{4}{*}{.802} \\
\hline & EPA2 & .703 & & \\
\hline & EPA3 & .730 & & \\
\hline & EPA4 & .693 & & \\
\hline
\end{tabular}

Notes: (1) $\mathrm{CR}=$ Composite reliability; $\mathrm{AVE}=$ Average variance extracted; $\mathrm{EP}=$ environmental performance; $\mathrm{EPA}=$ environmental proactivity; EMA = environmental management accounting

Table 4. Fornell and Larcker criterion

\begin{tabular}{cccc}
\hline Variables & EMA & EP & EPA \\
\hline EMA & 0.769 & & \\
EP & 0.701 & 0.751 & \\
EPA & 0.713 & 0.685 & 0.709 \\
\hline
\end{tabular}

Table 5. Factor loadings and reliability

\begin{tabular}{cccc}
\hline & EMA & EP & EPA \\
\hline EMA1 & $\mathbf{0 . 7 9 3}$ & 0.519 & 0.554 \\
EMA2 & $\mathbf{0 . 7 5 4}$ & 0.439 & 0.495 \\
EMA3 & $\mathbf{0 . 7 4 8}$ & 0.599 & 0.485 \\
EMA4 & $\mathbf{0 . 7 8 1}$ & 0.58 & 0.655 \\
EP1 & 0.503 & $\mathbf{0 . 7 4 1}$ & 0.485 \\
EP2 & 0.565 & $\mathbf{0 . 7 7 7}$ & 0.578 \\
EP3 & 0.477 & $\mathbf{0 . 7 4 4}$ & 0.458 \\
EP4 & 0.59 & $\mathbf{0 . 7 9 3}$ & 0.532 \\
EP5 & 0.483 & $\mathbf{0 . 6 9 3}$ & 0.506 \\
EPA1 & 0.542 & 0.583 & $\mathbf{0 . 7 0 9}$ \\
EPA2 & 0.49 & 0.366 & $\mathbf{0 . 7 0 3}$ \\
EPA3 & 0.472 & 0.421 & $\mathbf{0 . 7 3}$ \\
EPA4 & 0.501 & 0.511 & $\mathbf{0 . 6 9 3}$ \\
\hline
\end{tabular}

Table 6. HTMT ratio for constructs

\begin{tabular}{ccc}
\hline & EMA & EP \\
\hline EP & 0.880 & \\
EPA & 0.890 & 0.890 \\
\hline
\end{tabular}

Some authors suggested a threshold level of the HTMT is 0.85 (Kline, 2011), and others proposed a value below 0.90 (Henseler et al., 2016). In summary, it can be comfortably concluded that discriminant validity in this paper is established (Table 6).

\section{Structural model}

Firstly, it is crucial to confirm that there are no collinearity issues in the structural model. The VIF value for each of the constructs was lower than the offending value of 3.3 (Diamantopoulos \& Sigouw, 2006), which confirmed no issue with collinearity in this paper. 
Table 7 exhibits the bootstrap result, EMA*EPA is significant with a p-value of $\mathrm{p}<0.05$ as the t-value shows 2.44 . This further elucidates the moderating effect of EPA on the relationship between EMA and EP. Although the relationship between EPA and EP, and EMA and EP were not hypothesized in the survey, these relationships were found to be significant. Thus, the positive relationship between EMA and EP would be stronger if the EPA is higher. Besides that, this study proved Dawson's (2013) plot which postulated relationship is stronger when hypothesis 1 is supported.

The $\mathrm{R}^{2}$ in this paper is 0.561 , indicating that the variable of EMA and the moderator which is EPA, explains $56.1 \%$ of the variance in EP. After the insertion of the moderation interaction term, $\mathrm{R}^{2}$ changed to 0.584 . The $\mathrm{R}^{2}$ change of 0.023 indicated that with the addition of one interaction term, the $\mathrm{R}^{2}$ changed about $2.3 \%$. This is also known as additional variance which confirms the moderation effect. Overall, $\mathrm{EP}\left(\mathrm{Q}^{2}=0.29\right)$ is greater than 0 (Hair, et al., 2014) signifying that exogenous variables have the predictive ability over the endogenous variable (Hair et al., 2017). In sum, EPA moderates the relationship between EMA and EP with a moderate effect size.

Table 7. Bootstrapping results on moderating relationship

\begin{tabular}{cccc}
\hline Path & std beta & t-value & p-values \\
\hline EPA -> EP & 0.32 & 3.83 & 0.00 \\
EMA -> EP & 0.43 & 5.45 & 0.00 \\
EMA*EPA -> EP & 0.13 & $2.44 * *$ & 0.01 \\
\hline
\end{tabular}

\section{DISCUSSION}

Some scholars believed ISO 14001 certificated companies are not necessarily associated with the development of organizational capabilities to achieve significant reductions in their negative environmental impacts (Aragón-Correa \& Rubio-López, 2007). Therefore, this paper decided to examine the role of EPA as a moderator between the EMA and EP relationship.

EPA refers to non-compliance voluntary actions undertaken by a company to reduce or avoid the adverse effect on the environment of its activity and/or product(s) (Menguc \& Ozanne, 2005). When companies experience higher EPA, they should be able to fully deploy its resources and capabilities for better EP. As such, moderation analysis in this paper supports H1.

Strategically and statically, it is important to promote environmentally conscious ideas to uphold sustainability which in turn contribute solutions to the economic and environmental challenges of a company. Due to the richness and usefulness of EPA magnitude, it has proven that it could be a source of competitive advantage and best used as a moderator to stimulate better EP. Thus, as expected, it was found that the interaction between EPA and EP is positive. Thus, the positive relationship between EMA and EP would be stronger if EPA is higher.

Relying on the theory of DC, Teece et al. (1997) described this theory as the ability of a firm to react to its external environment by continuously increasing its capabilities to gain a competitive advantage. Furthermore, the DC theory showed that the competitive advantage of companies lies in their management and organizational structures, influenced by the particular asset position and growth direction made in the past (Teece, 1997). EPA, therefore, fits into the DC's theory, which does not only depend on the company's internal environment by scheduling routine supports for the future market but also affects the effective exploitation of the supply chain capabilities (Liu, Zhu \& Seuring, 2017).

As expected, this paper made evident that EPA with various magnitudes of growth opportunities and quality improvements makes organizational characteristics more flexible and allows a higher degree of risk-taking and innovation. As a result, the higher the level of EPA, the higher the environmental initiatives within the stakeholders to show sensitivity towards the environment which have resulted in a more established relationship between EMA and EP.

\section{CONCLUSION}

This paper strengthens the theory of NRBV by incorporating EPA as a moderator in the framework to provide additional theoretical explanations for EP. The result gave new insight into the debate on the mixed results that have been produced to date (Vachon and Klassen, 2008; Iwata and Okada, 2011). These findings illustrated that EPA can help to increase the use of EMA to achieve higher levels of improvements in EP. In other words, it confirmed the relationship between environmental initiatives and environmental performance dimensions which may not always be direct. In summary, the higher EPA encourages companies to employ environmental managers to develop suitable strategies and be prepared to invest in risky ventures that benefit the business as well as the environment. Indeed, EPA helps a firm to exploit learning skills between employees and managers and will try to reduce ambiguity related to environmental protection and maximise usage of EMA within organisations to ease the transition towards ecological sustainability.

This paper contributes significantly to the theory. Specifically, in applying the theory of DC, the NRBV theory offers some new insights into the debate on the link between environmental efforts and performance results (Hart and Dowell, 2011). As these links are becoming more complex due to high environmental uncertainty, it is now essential for researchers to consider other factors that may have a potential impact on EP (Hart and Dowell, 2011; De Burgos-Jiminez et al., 2014). Besides, this paper responds to Hart and Dowell's (2011) call that recommended future researchers to 
consider other supporting constructs drawn from the theory of DC. This paper makes primary contributions in this regard. Consequently, this paper provides support for the indirect moderation effect of EPA.

\section{Implications and recommendation}

Most researchers analysed environmental performance using one distinct theory. This study discovered that using more than one theory could help overcome the potential weaknesses inherent in that theory. Current results may also help companies in deploying evidence-based practices in their fight towards environmental protection as well as making wise investment decisions. For instance, managers should continuously assess their sustainability activities, needs, and requirements through the use of EMA and further evaluate their decision making. Higher EPA approach will merely respond to challenges as they emerge. Besides, it helps the effort of Malaysia attaining Agenda 2030 and reaching the target of the industrial hub.

A holistic approach has taken companies from economic consideration to environmental and social approach. In light of this shift, policymakers and regulators can reinforce the positive association between EMA, environmental proactivity, and environmental performance by enacting regulations that foster improvements in the form of tax breaks and subsidies for environmental investment and environmentally proactive firms.

This study has some limitations that also provide fruitful avenues for further research. Potential bias may arise during the data collection as it was done within the setting of an emerging market. Future researches may also consider the nonISO 14001 companies to examine the extent of their environmental performance. Secondly, and more importantly, the limited potential use of only quantitative questionnaire in the paper shows the scarcity of empirical studies on EMA and EP in extant literature. This might be an essential aspect that should be integrated into future research as it may affect the outcome of the study.

\section{REFERENCES}

Agustia, D., Sawarjuwono, T., \& Dianawati, W. (2019). The mediating effect of environmental management accounting on green innovation - Firm value relationship. International Journal of Energy Economics and Policy, 9(2), $299-306$. https://doi.org/10.32479/ijeep.7438

Albertini, E. (2014). A descriptive analysis of environmental disclosure: A longitudinal study of French companies. Journal of Business Ethics, 121(2), 233-254.

Alisjahbana, A. (2016, September 14). Focusing on Indonesia's SDG priorities [Blog post]. The Jakarta Post. Retrieved from https://www.thejakartapost.com/academia/2016/09/14/focusing-on-indonesias-sdg-priorities.html

Alrazi, B., De Villiers, C., \& Van Staden, C. J. (2015). A comprehensive literature review on, and the construction of a framework for, environmental legitimacy, accountability and proactivity. Journal of Cleaner Production, 102, 44-57. doi:10.1016/j.jclepro.2015.05.022

Aragón-Correa, J. A., \& Rubio-Lopez, E. A. (2007). Proactive corporate environmental strategies: Myths and misunderstandings. Long Range Planning, 40(3), 357-381. doi:10.1016/j.lrp.2007.02.008

Ariffin, A. R. M. (2016). Environmental management accounting (EMA): Is there a need?. International Journal of Liberal Arts and Social Science, 4(6), 96-103. doi:10.96-103D-04521

Barreto, I. (2010). Dynamic capabilities: A review of past research and an agenda for the future. Journal of Management, 36(1), 256280. doi:10.1177/0149206309350776

Bebbington, J., \& Gray, R. (2001). An account of sustainability: failure, success and a reconceptualization. Critical Perspectives on Accounting, 12(5), 557-588. doi:10.1006/cpac.2000.0450

Braam, G. J., de Weerd, L. U., Hauck, M., \& Huijbregts, M. A. (2016). Determinants of corporate environmental reporting: The importance of environmental performance and assurance. Journal of Cleaner Production, 129, 724-734. doi:10.1016/j.jclepro.2016.03.039

Burritt, R. L., Hahn, T., \& Schaltegger, S. (2002). Towards a comprehensive framework for environmental management accounting Links between business actors and environmental management accounting tools. Australian Accounting Review, 12(28), 39-50. doi:10.1111/j.1835-2561.2002.tb00202.x

Buysse, K., \& Verbeke, A. (2003). Proactive environmental strategies: A stakeholder management perspective. Strategic Management Journal, 24(5), 453-470. doi:10.1002/smj.299

Chang, S., Van Witteloostuijn, A., Eden, L. (2010). From the Editors: common method management systems on corporate and environmental performance. J. Oper. Manag.variance in international business research. Journal of International Business Studies, 41 (2), 178-184

Christ, K. L., \& Burritt, R. L. (2016). ISO 14051: A new era for MFCA implementation and research. Revista de Contabilidad: Spanish Accounting Review, 19(1), 1-9. doi:10.1016/j.rcsar.2015.01.006

Christine, D., Yadiati, W., Afiah, N. N., \& Fitrijanti, T. (2019). The relationship of environmental management accounting, environmental strategy and managerial commitment with environmental performance and economic performance. International Journal of Energy Economics and Policy, 9(5), 458-464. doi:10.32479/ijeep.8284

Dawson, J. F. (2013). Moderation in management research: What, why, when, and how. Journal of Business and Psychology, 29(1), 1-19. doi:10.1007/s10869-013-9308-7

De Beer, P., \& Friend, F. (2006). Environmental accounting: A management tool for enhancing corporate environmental and economic performance. Ecological Economics, 58(3), 548-560. doi:10.1016/j.ecolecon.2005.07.026

de Burgos-Jiménez, J., Vázquez-Brust, D., Plaza-Úbeda, J. A., \& Dijkshoorn, J. (2013). Environmental protection and financial performance: an empirical analysis in Wales. International Journal of Operations \& Production Management, 33(8), 9811018. https://doi:10.1108/IJOPM-11-2010-0374 
Demirel, P., \& Kesidou, E. (2011). Stimulating different types of eco-innovation in the UK: Government policies and firm motivations. Ecological Economics, 70(8), 1546-1557. doi:10.1016/j.ecolecon.2011.03.019

Diamantopoulos, A., \& Siguaw, J. A. (2006). Formative versus reflective indicators in organizational measure development. A comparison and empirical illustration. British Journal of Management, 17(4), 263 - 282.

Dubey, R., Gunasekaran, A., \& Samar Ali, S. (2015). Exploring the relationship between leadership, operational practices, institutional pressures and environmental performance: A framework for green supply chain. International Journal of Production Economics, 160, 120-132.

Friedman, M. (1970, September 13). The social responsibility of business is to increase its profits. corporate ethics and corporate governance. The New York Times Magazine. doi:10.1007/978-3-540-70818-6_14

Gan, P. Y., Komiyama, R., \& Li, Z. (2013). A low carbon society outlook for Malaysia to 2035. Renewable and Sustainable Energy Reviews, 21, 432-443. doi:10.1016/j.rser.2012.12.041

Garcés-Ayerbe, C., Rivera-Torres, P., \& Murillo-Luna, J. L. (2012). Stakeholder pressure and environmental proactivity: Moderating effect of competitive advantage expectations. Management Decision, 50(2), 189-206. doi:10.1108/00251741211203524

González-Benito, J., \& González-Benito, Ó. (2005). Environmental proactivity and business performance: An empirical analysis. Omega, 33(1), 1-15. https://doi:10.1016/j.omega.2004.03.002

González-Benito, J., \& González-Benito, Ó. (2006). A review of determinant factors of environmental proactivity. Business Strategy and the Environment, 15(2), 87-102. https://doi:10.1002/bse.450

Hair J. F., Hult G. T. M., Ringle C. M., Sarstedt M. (2014). A Primer on Partial Least Squares Structural Equation Modeling (PLSSEM). Thousand Oaks: SAGE Publications.

Hair, J. F., Hult, G. T. M., Ringle, C. M., \& Sarstedt, M. (2017). A primer on partial least squares structural equation modeling (PLSSEM) (2nd ed.). SAGE Publications.

Hart, S. L. (1995). A natural-resource-based view of the firm. Academy of Management Review, $20(4), 986-1014$. doi:10.5465/amr.1995.9512280033

Hart, S.L., \& Dowell, G. (2011). A natural-resource-based view of the firm: Fifteen years after. Journal of Management, 37(5), 14641479.

Henseler, J., Hubona, G., \& Ray, P. A. (2016). Using PLS path modeling in new technology research: updated guidelines. Industrial management \& data systems.

Hsu, C. W., Lee, W. H., \& Chao, W. C. (2013). Materiality analysis model in sustainability reporting: A case study at Lite-On Technology Corporation. Journal of Cleaner Production, 57, 142-151. doi:10.1016/j.jclepro.2013.05.040

International Federation of Accountants. (2005). International Guidance Document: Environmental Management Accounting. https://www.icjce.es/images/pdfs/TECNICA/C01\%20-\%20IFAC/C.01.010\%20$\% 20 \mathrm{General} /$ Int $\% 20 \mathrm{Guidance} \% 20 \mathrm{Doc} \% 20$ on\%20EMA\%20-\%20Agosto\%202005.pdf

International Standard Organization. (2011). ISO 14051:2011 Environmental management - Material flow cost accounting - General framework. https://www.iso.org/standard/50986.html

Iwata, H., \& Okada, K. (2011). How does environmental performance affect financial performance? Evidence from Japanese manufacturing firms. Ecological Economics, 70(9), 1691-1700. https://doi:10.1016/j.ecolecon.2011.05.010

Jalaludin, D., Sulaiman, M., Ahmad, N. (2010). Environmental management accounting: an empirical investigation of manufacturing companies in Malaysia. Journal of Asia-Pacific Centre Env. Accountability 16 (3), 31-45.

Jasch, C., \& Lavicka, A. (2006). Pilot project on sustainability management accounting with the Styrian automobile cluster. Journal of Cleaner Production, 14(14), 1214-1227. doi:10.1016/j.jclepro.2005.08.007

Kline, R. B. (2011). Principles and practice of structural equation modeling. New York: Guilford Press.

Konar, S., \& Cohen, M. A. (2001). Does the market value environmental performance? Review of Economics and Statistics, 83(2), 281-289. doi:10.1162/00346530151143815

Latan, H., Chiappetta Jabbour, C. J., Lopes de Sousa Jabbour, A. B., Wamba, S. F., \& Shahbaz, M. (2018). Effects of environmental strategy, environmental uncertainty and top management's commitment on corporate environmental performance: The role of environmental management accounting. Journal of Cleaner Production, 180, $297-306$.

Lee, S. Y., \& Rhee, S. K. (2007). The change in corporate environmental strategies: A longitudinal empirical study. Management Decision, 45(2), 196-216. doi:10.1108/00251740710727241

Liu, Y., Zhu, Q., \& Seuring, S. (2017). Linking capabilities to green operations strategies: The moderating role of corporate environmental proactivity. International Journal of Production Economics, 187, 182-195. doi:10.1016/j.ijpe.2017.03.007

Mehrabi, Z., Donner, S., Rios, P., Guha-Sapir, D., Rowhani, P., Kandlikar, M., \& Ramankutty, N. (2019). Can we sustain success in reducing deaths to extreme weather in a hotter world? World Development Perspectives, 14, 100107.

Mekhilef S, Saidur R, Safari A. (2011). A review on solar energy use in industries. Renew Sustain Energy Rev, 15(4):17771790 .

Menguc, B., \& Ozanne, L. K. (2005). Challenges of the "green imperative": A natural resource-based approach to the environmental orientation-business performance relationship. Journal of Business Research, 58(4), 430-438.

Nawrocka, D., \& Parker, T. (2009). Finding the connection: Environmental management systems and environmental performance. Journal of cleaner production, 17(6), 601-607.

Qian, W., Burritt, R., \& Monroe, G. (2011). Environmental management accounting in local government: A case of waste management. Accounting, Auditing \& Accountability Journal, 24(1), 93-128. doi:10.1108/09513571111098072

Rao, P. (2002). Greening the supply chain: A new initiative in South East Asia. International Journal of Operations \& Production Management, 22(6), 632-655. doi:10.1108/01443570210427668

Rikhardsson, P. M., Bennett, M., Bouma, J. J., \& Schaltegger, S. (2005). Environmental management accounting: Innovation or managerial fad?. In P. M. Rikhardsson, M. Bennett, J. J., Bouma, \& S. Schaltegger (Eds.), Implementing environmental management accounting: Status and challenges (pp. 1-16). The Netherlands: Springer.

Roberts, L., \& Gehrke, T. (1996). Linkages between best practice in business and good environmental performance by companies. Journal of Cleaner Production, 4(3-4), 189-202. https://doi:10.1016/s0959-6526(96)00039-x

Sambasivan, M., Bah, S. M., \& Jo-Ann, H. (2013). Making the case for operating "Green": impact of environmental proactivity on multiple performance outcomes of Malaysian firms. Journal of Cleaner Production, 42, 69-82. doi:10.1016/j.jclepro.2012.11.016 
Schaltegger, S. (2018). Linking environmental management accounting: A reflection on (missing) links to sustainability and planetary boundaries. Social and Environmental Accountability Journal, 38(1), 19-29. https://doi:10.1080/0969160x.2017.1395351

Searcy, C., \& Elkhawas, D. (2012). Corporate sustainability ratings: An investigation into how corporations use the Dow Jones Sustainability Index. Journal of Cleaner Production, 35, 79-92. doi:10.1016/j.jclepro.2012.05.022

Setthasakko, W. (2010). Barriers to the development of environmental management accounting: An exploratory study of pulp and paper companies in Thailand. EuroMed Journal of Business, 5(3), 315-331. doi:10.1108/14502191011080836

Tajelawi, O. A., \& Garbharran, H. L. (2015). MFCA: An environmental management accounting technique for optimal resource efficiency in production processes. International Journal of Mechanical and Industrial Engineering, 9(11), 3765-3770.

Teece, D. J. (2010). Business models, business strategy and innovation. Long Range Planning, 43(2-3), $172-194$. doi:10.1016/j.lrp.2009.07.003

Teece, D. J. (2014). The foundations of enterprise performance: Dynamic and ordinary capabilities in an (economic) theory of firms. Academy of Management Perspectives, 28(4), 328-352. https://doi:10.5465/amp.2013.0116

Teece, D. J., Pisano, G., \& Shuen, A. (1997). Dynamic capabilities and strategic management. Strategic Management Journal, 18(7), 509-533. doi:10.1002/(sici)1097-0266(199708)18:7<509::aid-smj882>3.0.co;2-z

Vachon, S., \& Klassen, R. D. (2008). Environmental management and manufacturing performance: The role of collaboration in the supply chain. International Journal of Production Economics, 111(2), 299-315. https://doi:10.1016/j.ijpe.2006.11.030

Vishwakarma, A. K., Nema, A. K., \& Sangle, S. (2019). What determines environmental proactiveness in the Indian cement sector? An empirical study. Journal of Cleaner Production, 234, 961-971. doi:10.1016/j.jclepro.2019.06.291

Wagner, M., Van Phu, N., Azomahou, T., \& Wehrmeyer, W. (2002). The relationship between the environmental and economic performance of firms: An empirical analysis of the European paper industry. Corporate Social Responsibility and Environmental Management, 9(3), 133-146. https://doi:10.1002/csr.22

Yakhou, M., \& Dorweiler, V. (2004). Environmental accounting: An essential component of business strategy. Business Strategy and the Environment, 13(2), 65-77.

Zhou, Z., Zhao, W., Chen, X., \& Zeng, H. (2017). MFCA extension from a circular economy perspective: Model modifications and case study. Journal of Cleaner Production, 149, 110-125. https://doi.org/10.1016/i.jclepro.2017.02.049.

\section{ACKNOWLEDGEMENT}

This work was funded by Geran Putra 2017 (GP/2017/9573000)

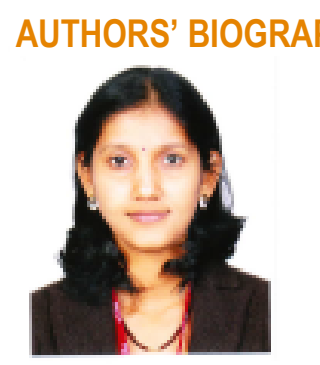

Jeya Santhini Appannan is a lecturer from University Tunku Abdul Rahman (UTAR) and a member of the Malaysian Institute of Accountants. She is a PhD student at School of Business and Economics, University Putra Malaysia (UPM). Her research interest include environmental accounting and corporate sustainability.

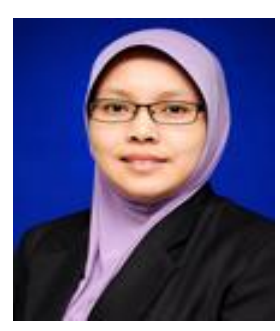

Mohd Said R. is an Associate Professor at University Putra Malaysia, and currently a member for the Malaysian Institute of Accountants. She holds a PhD from International Islamic University Malaysia. Her field of specialisation are environmental accounting, sustainability and green reporting. She has published a good number of articles in local and international journals.

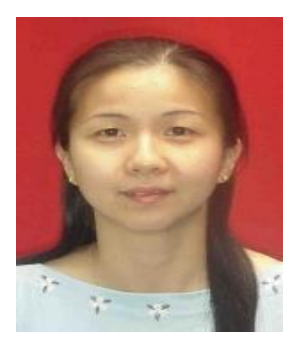

Tze San is an Associate Professor at University Putra Malaysia. She earned her PhD from University of Leeds, UK in 2005. She has published more than 100 academic articles both local and internationally. Her research interests include corporate sustainability, corporate performance measurement system, corporate governance, management accounting and carbon accounting.

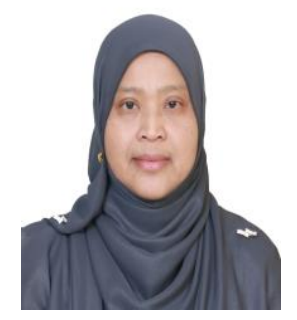

Rosmila Senik is a senior lecturer at School of Business and Economics, University Putra Malaysia (UPM). Main courses taught are accounting, information systems, business ethics and corporate governance, and basic entrepreneurship. Among her research interests are financial and managerial reporting quality, and information technology applications in accounting education and SMEs. 